\title{
Clear cell renal carcinoma metastasis in the oral cavity - Case report
}

\author{
Paweł Milner ${ }^{1}$, Anna Janas ${ }^{2}$, Grażyna Grzesiak-Janas ${ }^{1}$ \\ 1 Department of Oral Surgery, Medical University of Lodz, Poland \\ 2 Department of General Dentistry, Medical University of Lodz, Poland
}

Milner P, Janas A, Grzesiak-Janas G. Clear cell renal carcinoma metastasis to the oral cavity - Case report. J Pre-Clin Clin Res. $2014 ;$ 8(2): 127-129. doi: $10.5604 / 18982395.1135666$

\begin{abstract}
Introduction. Metastatic renal cell carcinoma can spread from the primary renal cell carcinoma to other organs, practically to all tissues. Distant metastases - to the tissue of the head and neck - are transferred through the blood and lymph vessels. A case of such a metastasis localized on the palate is relatively rare and therefore poses interesting material for description. Objective. Analysis of a case of cell renal carcinoma meastasis of the palate in a 67-year-old patient, based on clinical observations and medical publications.

Conclusion. Clear cell carcinoma metastases to distant organs are often the first sign of a covertly progressing disease of which the primary tumour is localized in the kidney. The treatment is surgical, and prognosis is poor in the case of distant metastases since tumours recur even after a few years.
\end{abstract}

\section{Key words}

carcinoma metastases, renal cell carcinoma

\section{INTRODUCTION}

Carcinoma metastases from distant organs to the facial part of the skull account for approximately $1 \%$ of malignant tumors in these structures. In their pathogenesis, it is the tumours which spread within cavities which are more common, less frequently they metastasize through blood and lymph. The jaw, especially the mandible, happens to be the destination of metastases of lung as well as prostate, kidney, thyroid and testicular carcinoma [1]. Kidney cancer constitutes approx. $2-3 \%$ of all malignant cancers in adults. It is more common in men, usually in the 5th -6th decade of life [2].

The most frequent histopathological type of this cancer is clear cell renal carcinoma (carcinoma clarocellulare), which occurrs in $75-85 \%$ of cases. This malignant epithelial tumour originates in the proximal tubular cells in the glomeruli [3]. Since the available medical publications in the Polish language do not contain a description of a clear cell renal carcinoma metastasis to the palate, it seems beneficial to present this case.

\section{Objective}

Presentation of a case report of a patient with clear cell renal carcinoma metastasis to the palate.

\section{CASE REPORT}

A 67-year-old male patient presented with a lesion on the hard palate mucosa on the right side, which he had noticed 3 months prior to the visit and which he had associated with pain and pressure caused by the plate of acrylic denture fitted 2 years before which, according to the patient, was badly anchored.

Address for correspondence: Pawel Milner, Department of Oral Surgery, 251 Pomorska Street, 92-213 Lodz, Poland

E-mail: pawelmilner@wp.pl

Received: 24 July 2014; accepted: 16 October 2014
The history of the patient included hypertension, bronchial asthma and prostatic hyperplasia. He has been hospitalized in the last 5 years due to urinary tract infection; however, he had never been diagnosed or treated oncologically. The patient does not recall cancer cases in the family, neither in parents nor grandparents, has never smoked and his describes alcohol consumption as occasional (no more than once in a month). On the day of the examination, the patient was in good physical condition, but showed anxiety caused by the unhealing lesion on the mucosa.

On examination, the patient's face was symmetrical, a melanocytic nevus about $6 \mathrm{~mm}$ in diameter was detected $1 \mathrm{~cm}$ below the left eyeball. On palpation, the fifth cranial nerve was asymptomatic, submandibular lymph nodes of group $\mathrm{B}$ and $\mathrm{C}$ bilaterally mobile, slightly tender on the right side. Jaw dilation was within limits.

Intraorally, a tender irregularly shaped lump approx. $2-3 \mathrm{~cm}$ in diameter was detected on the hard palate on the right side. It transformed into inflammatory lesion reaching the retromolar space and the soft palate (Fig. 1).

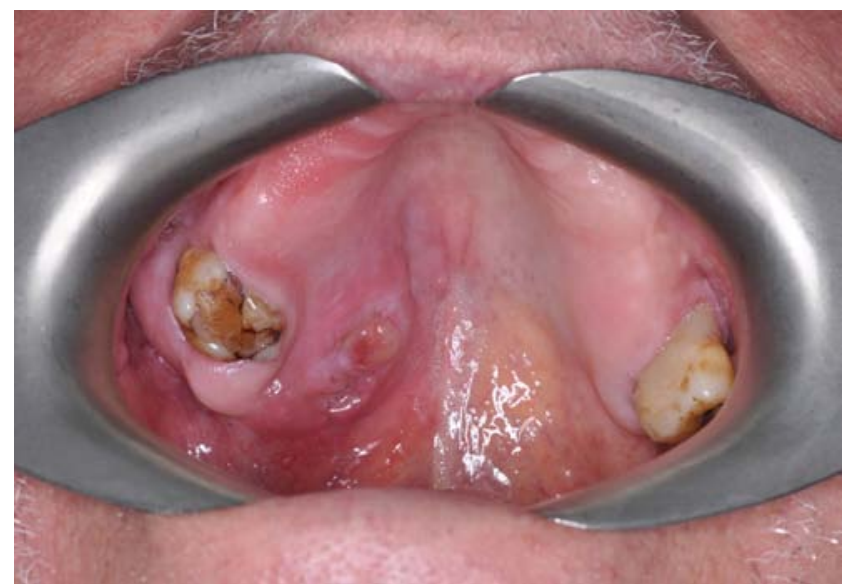

Figure 1. Lesion on the hard palate mucosa on the right side which in the course of diagnosis proved to be secondary clear cell renal carcinoma 
Characteristically, the border line between the changed section of the palate and the unaffected one where the mucosa was intact was clearly marked by the mid-palatal suture. The examined area was complementarily diagnosed with the fluorescence imaging, with the use of VELscope VX, which revealed a decline in autofluorescence (manifested as dark patches) within the diagnosed lesion (Fig. 2). The patient's dental radiography - panoramic (Fig. 3) and palatal x-ray (Fig. 4) - did not show any changes in the bone structure of the affected area, which pointed to an early stage of the metastasis and its appearance in the soft tissues rather than the bones.

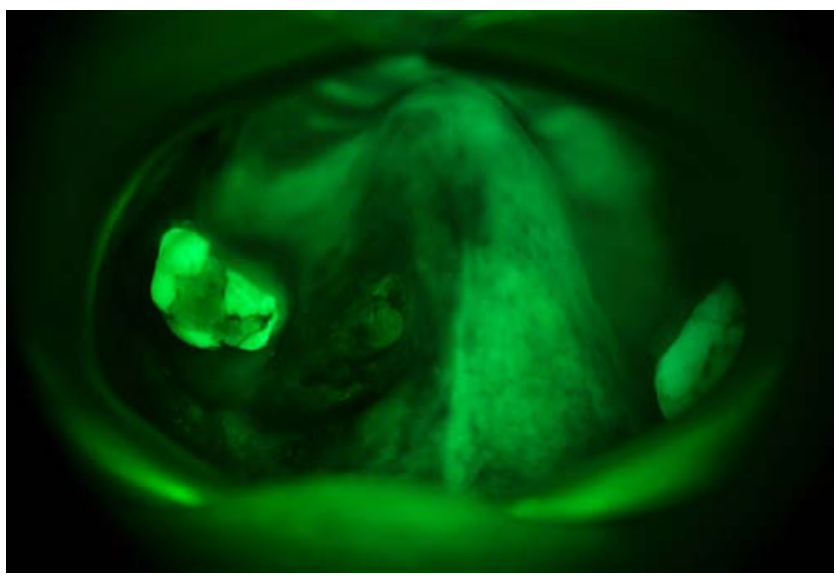

Figure 2. Fluorescence image of the lesion achieved by mounting a photo camera on the VELscope VX device

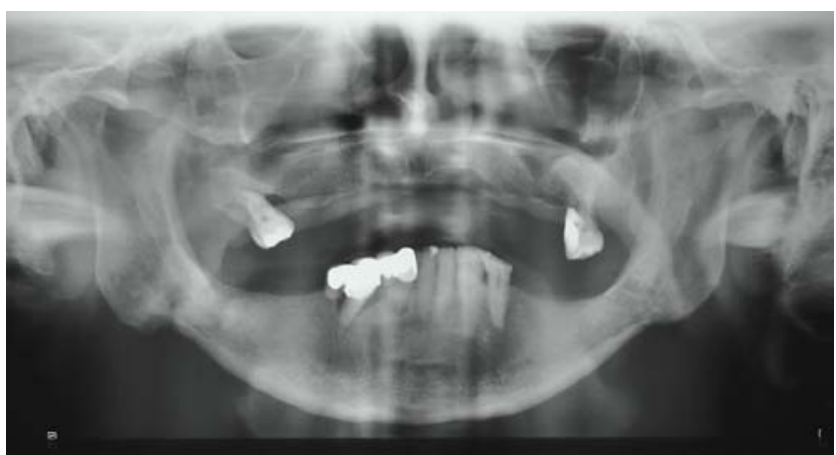

Figure 3. Panoramic radiography of the 67-year-old patient

In order to verify the staging of the disease, the patient was presented with the plan of treatment and after informed consent had been obtained signed, the treatment followed. Under a local anesthesia of $2 \%$ lignocaine, the lesion on the hard palate on the right side was excised, and the postoperative wound sutured. The tissue was sent for histopathological examination to the Pathomorphology Department of Łódź Medical University. The results (No. 7189/2013) showed a lesion of poorly differentiated carcinoma and partially differentiated clear cell.

The patient was urgently admitted to the local Oncologic Care Ward at the Copernicus Memorial Hospital in Łódź for further specialist treatment. He was diagnosed with primary clear cell carcinoma of the right kidney (carcinoma clarocellulare) and underwent surgery and chemotherapy.

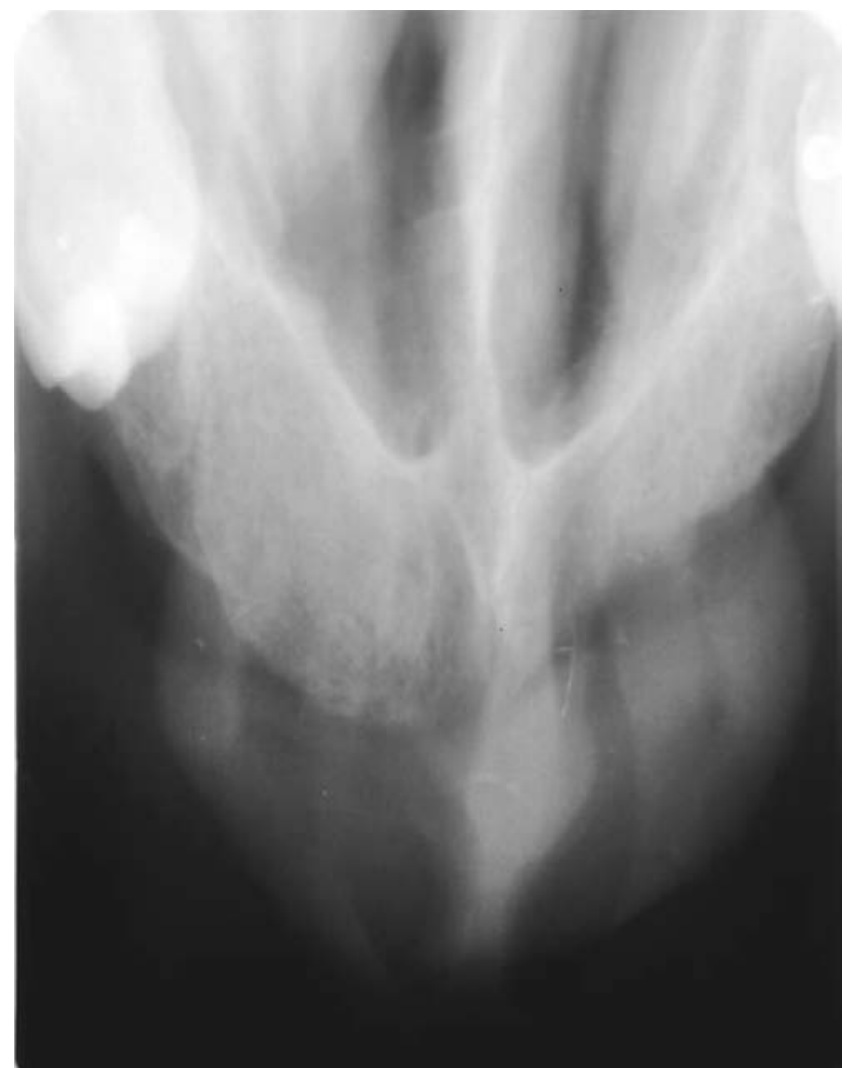

Figure 4. Patient's palatal X-Ray

\section{DISCUSSION}

Clear cell renal carcinoma is composed of cells with light cytoplasm containing large amounts of triglycerides and phospholipids which, during histopathological slide preparation, are washed awal, thus creating an image of 'empty cells' surrounded by a thick network of capillaries. The tumour develops covertly over a long period of time, the secondary carcinoma often being the first its sign [4], which happened in the case described. According to Stodulski et al. [3], about $30 \%$ of renal carcinomas are diagnosed on the basis of neurological symptoms. Notably, an early sign is an invasion to the renal vein (30\%) and inferior vena cava (4-10\%), which results in a high risk of metastases, most commonly, to the lungs (55\%), lymph nodes (34\%), liver (33\%), bones (32\%), adrenal glands (19\%), opposite kidney (11\%), brain $(6 \%)$, heart $(5 \%)$, spleen $(5 \%)$, colon $(4 \%)$, skin $(3 \%)$, and other places [5]. Metastases can rarely occur in distant structures, such as lymph nodes and bones of the facial skull [6]. The mode of transmission to the head and neck are via the vertebral vessels bundles [7]. Very high metastasis potential of the clear cell renal carcinoma stems from the fact that the kidney is a highly vascularized organ (about $25 \%$ of the total blood volume runs through the kidneys within one minute). Furthermore, the carcinoma cells are adaptive in a varied microenvironment [3].

In Polish medical publications, mostly casuistic descriptions of the metastasis to the nasal cavity and paranasal sinuses are presented $[8,9,10]$. Some carcinomas have been reported to have metastasized to the body of the mandible [6], frontal bone [11] or the tongue [12]. Rare descriptions concern metastases to the larynx, pharynx, submandibular and 
parotid salivary glands, palatine Tonsil and brain [13]. The accessible literature does not provide a description of clear cell renal carcinoma metastasis to the palate, except for a single reference of a metastasis to the ethmonasal complex (Hayes et al., 1985), [14]. Secondary carcinomas may appear in virtually any part of the body [15]. The carcinoma and its metastases develop relatively slowly due to the presence of a capsule [8]. It is difficult to predict the clinical advances of the disease, particularly as far as the timing, location, and pace of the tumour growth are concerned.

Clear cell renal carcinoma is treated surgically since radiotherapy is ineffective due to its low radiation sensitivity [8]. The aforementioned patient's treatment in the local Oncologic Care Ward at the Copernicus Memorial Hospital in Łódź included surgery of the primary carcinoma, followed by chemotherapy. The patient is currently being prepared for jaw resection procedure to excise the secondary carcinoma on the palate.

\section{CONCLUSION}

The kidney is the third organ (after the lung and nipple) below the clavicle the metastasis of which can be observed in the tissues of the head and neck. The presented case confirms that such metastases are the first sign of a covertly developing disease. Diagnosis of clear cell carcinoma within the structures of the head and neck should be accompanied by a search for a primary carcinoma in the kidneys [2]. The high vascularization of the renal carcinoma indicates surgical treatment similar to that for a vascular tumour [3]. The prognosis in the case of a distant metastasis, even after radical surgery, is poor as remissions are likely to occur.

\section{REFERENCES}

1. Kamiński B, Kobiorska-Nowak J, Bień S. Przerzuty nowotworowe do jam nosa i zatok przynosowych z narządów odległych [Cancer metastases to nasal cavity and paranasal sinuses from distant organs]. Otolaryngol Pol. 2008; LXII(4): 422-425 (in Polish).
2. Lewandowski B, Pakla P. Przerzut raka jasnokomórkowego nerki do tkanek jamy ustnej [Metastasis of clear cell renal cell carcinoma to oral cavity tissues]. Czas Stomatol. 2009; 62(12): 962-967 (in Polish).

3. Stodulski D, Stankiewicz C, Skorek A. Przerzuty raka nerki do narządów głowy i szyi [Metastases of renal carcinoma of the head and neck region]. Otolaryngol Pol. 2006; LX(6): 893-899 (in Polish).

4. Stańczyk R, Omulecka A, Pajor A. Przerzut raka jasnokomórkowego nerki do części ustnej gardła [Metastasis of clear cell renal cell carcinoma in the oral part of throat]. Otolaryngol Pol. 2006; LX(1): 97-100 (in Polish).

5. Paulson D, Perez C, Anderson T. Cancer of the kidney and ureter., Cancer Principles. Practice Oncology. Philadelphia, J.B. Lippincott, 1985.

6. Rudziński L, Dąbrowski K. Rzadki przypadek przerzutu raka jasnokomórkowego nerki do trzonu żuchwy [Rare case of metastasis of clear cell renal cell carcinoma of the body of the mandible]. Wiad Lek. 1984; XXXVII(14): 1122-1124 (in Polish).

7. Jordan J, Cieszyńska J, Stalke M. Przerzuty nowotworowe do głowy i szyi z narządów odległych [Cancer metastases of the head and neck from distant organs]. Otolaryngol Pol. 2004; 58: 459-467 (in Polish).

8. Pietniczka M, Kukwa A, Tulibacki M. Krwotok z nosa pierwszym objawem raka nerki [Nose bleeding as the first symptom of renal carcinoma]. Otolaryngol Pol. 1992; XLVI(6): 615-618 (in Polish).

9. Szlenk Z, Osuch-Wójcikiewicz E, Janczewski G. Przerzut raka jasnokomórkowego nerki do głowy i szyi [Metastasis of clear cell renal cell carcinoma of the head and neck]. Otolaryng Pol. 1994; XLVIII(2): 203-208 (in Polish).

10. Cieszyńska J, Stalke M, Sova J. Krwotok z nosa jako pierwszy objaw przerzutu raka nerki [Nose bleeding as the first sign of metastasis renal carcinoma]. Otorynolaryngologia 2003; 2(3): 138-140 (in Polish).

11. Białowąs J, Bulińska H, Słuszkiewicz-Potaż Z. Przerzut raka jasnokomórkowego nerki do kości czołowej [Metastasis of clear cell renal cell carcinoma of the frontal bone]. Otolaryngol Pol. 1978; XXXII(2): 221-225 (in Polish).

12. Kuźniar A, Downar-Zapolski Z. Rzadki przypadek późnego przerzutu raka jasnokomórkowego nerki do języka [Rare case of late metastasis of clear cell renal cell carcinoma of the tongue]. Otolaryngol Pol. 1979; XXXIII(6): 665-667 (in Polish).

13. Stankiewicz C, Mostowski L. Przerzut raka jasnokomórkowego nerki do krtani [Metastasis of clear cell renal cell carcinoma of the larynx]. Otolaryngol Pol. 1973; 33(5): 543-545 (in Polish).

14. Hayes E, Weber AL, Davis KR, Arring FG. Metaplastic renal cell carcinoma manifesting as a nasal mass: CT findings. J Comput Assist Tomogr. 1985; 9(2): 387.

15.Zygulska A, Wójcik A, Richter P. Przerzut raka nerki do pęcherzyka żółciowego - opis przypadku [Metastasis of renal carcinoma of the gall bladder - Case report]. Onkol Prak Klin. 2009; 5(6): 261-262 (in Polish). 